\title{
To See The Impact Of Various Interventions On Staff Knowledge And Compliances By Conducting Waste Audit In Kpj Seremban Specialist Hospital Malaysia
}

\author{
${ }^{1}$ A R. Abdul Aziz, ${ }^{2}$ M B. Nishazini, ${ }^{3}$ U. Azlina, ${ }^{4}$ N. A.Azizan \\ ${ }^{1}$ KPJ Seremban Specialist Hospital \\ ${ }^{2}$ KPJ Seremban Specialist Hospital \\ ${ }^{3}$ KPJ Seremban Specialist Hospital \\ ${ }^{4}$ University Malaysia Pahang
}

\begin{abstract}
In April 2012, a survey was conducted by distributing questionnaires to all staff focusing on staff compliance and knowledge in managing hospital wastes. 500 questionnaires had been distributed. However only 363 questionnaires had been collected which is $72.6 \%$ of the sample. After the survey, various interventions had been carried out from May 2012 to September 2012 including producing the guidelines to manage hospital wastes, continuous teaching for all staff, monthly briefing at every department and monthly round by a team headed by outsource officer who is in charge of waste management to check the compliance, guidelines on audit of waste and training of head of departments on how to conduct waste audit.

In October 2012 , waste audit was conducted to find out the compliance among staff including clinical waste, chemical waste, domestic and food waste, electrical and electronic equipment waste. Audit check points include consignment notes, reports as required by laws and regulations, handling, segregation, storage, collection, transportation and disposal. Results were later compared to both national and international benchmarking .The clinical and chemical waste generated in KPJ Seremban were 39\% compared to 20\%-40\% for Malaysian hospitals and 15\% for American hospital. For domestic and kitchen waste, KPJ Seremban generated $61 \%$ compared to 60\%-80\% for Malaysia hospitals and 85\% for American hospitals. Therefore KPJ Seremban was within the national and international standards.
\end{abstract}

Key Words: Hospital wastes, survey, waste audit, benchmarking

\section{Introduction}

Environmental Quality Act (EQA) 1974 is the only Act so far on environmental protection in Malaysia. It was officially released in 1974, and has been amended over the years in 1986, 1996, 1998 and 2001.The Act, commonly called EQA 1974, is an "Act relating to the prevention, abatement, control of pollution and enhancement of the environment and for purposes connected therewith". The EQA 1974, should be read in conjunction with the subsidiary regulations, orders and guidelines . In the 2007 amendments, very slight changes were made on Section $34 \mathrm{~B}(4)$ and 43 only as noted in the EQA.

In Malaysia the clinical waste is being classified as scheduled waste that is controlled under the Environmental Quality(Schedule Wastes) Regulation, 1989.This is in line with the international classification of clinical and related wastes arising from medical, nursing, dental, veterinary or similar practices. In the course of implementing the scheduled wastes regulations, clinical waste generators may refer to this guidelines for the handling and management of clinical wastes to assist them to comply with the requirements of the Environmental Quality(Scheduled Wastes) Regulations, 1989

The safe and effective disposal of healthcare waste starts with the health care practitioner. There is a very real need to reduce both the cost and environmental impact arising from the generation and disposal of waste in health care setting( RCN Guide 2007).

In order to effectively manage healthcare waste, all those involved in the management of the waste stream should have access to an appropriate healthcare waste policy which clearly identifies who is responsible for the waste and how it should be managed. The policy should clearly identify the legal obligations set out in waste, health and safety and carriage legislation.

Healthcare waste includes all the waste generated by healthcare establishments, research facilities and laboratories. In addition it includes the waste originating from minor scattered sources originating from minor or scattered sources such as that produce in the course of healthcare undertaken in the home such as dialysis, insulin injections and so on . Healthcare waste is a byproduct of healthcare that includes sharps, non-sharps, blood, body parts, chemicals, pharmaceuticals, medical devices and radioactive materials (WHO) 
The appropriate handling and disposal of wastes generated from hospital is essential to avoid adverse health and environmental consequences. Healthcare services have to ensure better health inevitably create waste that may itself be hazardous to health as it may contain infectious and contaminated with hazardous materials. Therefore, KPJ Seremban had conducted a study to find out the level of understanding among staff and based on that study various interventions had been implemented. Finally waste audit was conducted to see the percentage of compliance compared to local and international benchmarking. By looking at the result, the management can see the impact of various interventions that had been carried out to improve knowledge among staff so that it will improve compliances on the management of hospital waste.

\section{Objectives}

- To find out the level of understanding among staff in managing hospital waste

- To find out the result of waste audit conducted

- To see the impact of various interventions to improve level of knowledge among staff by using the outcome of waste audit

\section{Methodology}

A survey was conducted by distributing questionnaires to all staff in April 2012 focusing on staff compliance and knowledge in managing hospital wastes. 500 questionnaires had been distributed. However only 363 questionnaires had been collected. After the survey, various interventions had been carried from May 2012 to September 2012 to improve knowledge of staff so that they will comply to the requirements of hospital waste management. Interventions carried out include the guidelines to manage hospital wastes, continuous teaching for all staff, monthly briefing at every department and monthly round by a team headed by outsource officer who is in charge of waste management to check the compliance, the management produced guidelines on audit of waste and training of head of departments on how to conduct waste audit.

In October 2012 ,waste audit was conducted to find out the compliance among staff. Waste audits include clinical waste, chemical waste, domestic and food waste, electrical and electronic equipment waste. Audit check points include consignment notes, reports as required by laws and regulations, handling, segregation, storage, collection, transportation and disposal. Results were later compared to both national and international benchmarking .

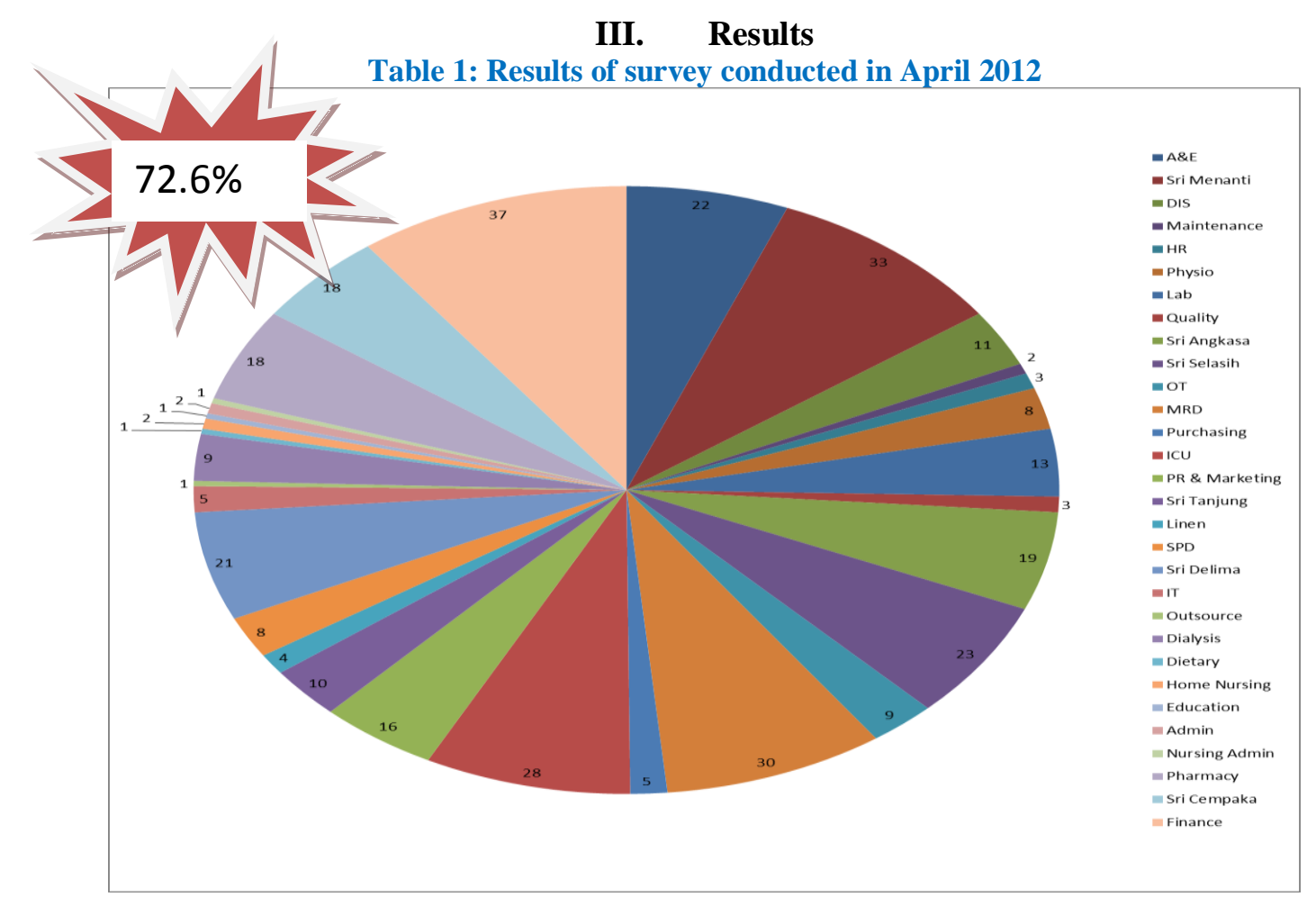

Total questionnaires distributed: 500

Total questionnaires collected : 363

Percentage collected: $72.6 \%$

Table 2: Grading scale used for results of the survey 
To See The Impact Of Various Interventions On Staff Knowledge And Compliances By Conducting

\begin{tabular}{|c|c|}
\hline Wrong Answers & Grade \\
\hline 1 & 86 \\
\hline 2 & 71 \\
\hline 3 & 57 \\
\hline 4 & 43 \\
\hline 5 & 29 \\
\hline 6 & 14 \\
\hline 7 & 0 \\
\hline
\end{tabular}

\begin{tabular}{|l|l|}
\hline Grade & Points \\
\hline Excellent & $100-90$ \\
\hline Very good & $89-75$ \\
\hline Good & $74-60$ \\
\hline Fail & 59 and less \\
\hline
\end{tabular}

Grading was based on the guidelines produced by University of Economy, Parague

(Ref: : http://web.weatherfordisd.com/EmployeesLinks/tools/GradeCalc.asp)

Table 3: Results for each question answered by staff

\begin{tabular}{|l|l|l|l|}
\hline NO & TYPES OF QUESTION & $\begin{array}{l}\text { RIGHT } \\
\text { ANSWER(\%) }\end{array}$ & $\begin{array}{l}\text { WRONG } \\
\text { ANSWER(\%) }\end{array}$ \\
\hline 1. & $\begin{array}{l}\text { How many types of schedule waste are there if KPJ } \\
\text { Seremban }\end{array}$ & $\mathbf{1 3 . 5 0}$ & $\mathbf{8 6 . 5 0}$ \\
\hline 2. & Please select the best statement to describe schedule waste & $\mathbf{7 4 . 6 6}$ & $\mathbf{2 5 . 3 4}$ \\
\hline 3. & $\begin{array}{l}\text { How many times the clinical waste and general waste to be } \\
\text { collected }\end{array}$ & $\mathbf{2 6 . 1 7}$ & $\mathbf{7 3 . 8 3}$ \\
\hline 4. & Waste shall be collected by ? & $\mathbf{9 2 . 2 0}$ & $\mathbf{7 . 8 0}$ \\
\hline 5. & Color coding system for waste bin & $\mathbf{6 5 . 8 4}$ & $\mathbf{3 4 . 1 6}$ \\
\hline 6. & Color coding system for waste bag & $\mathbf{7 9 . 3 4}$ & $\mathbf{2 0 . 6 6}$ \\
\hline 7. & Appropriate PPE being used & $\mathbf{8 5 . 6 7}$ & $\mathbf{1 4 . 3 3}$ \\
\hline
\end{tabular}

Figure 1: Grading for nursing staff

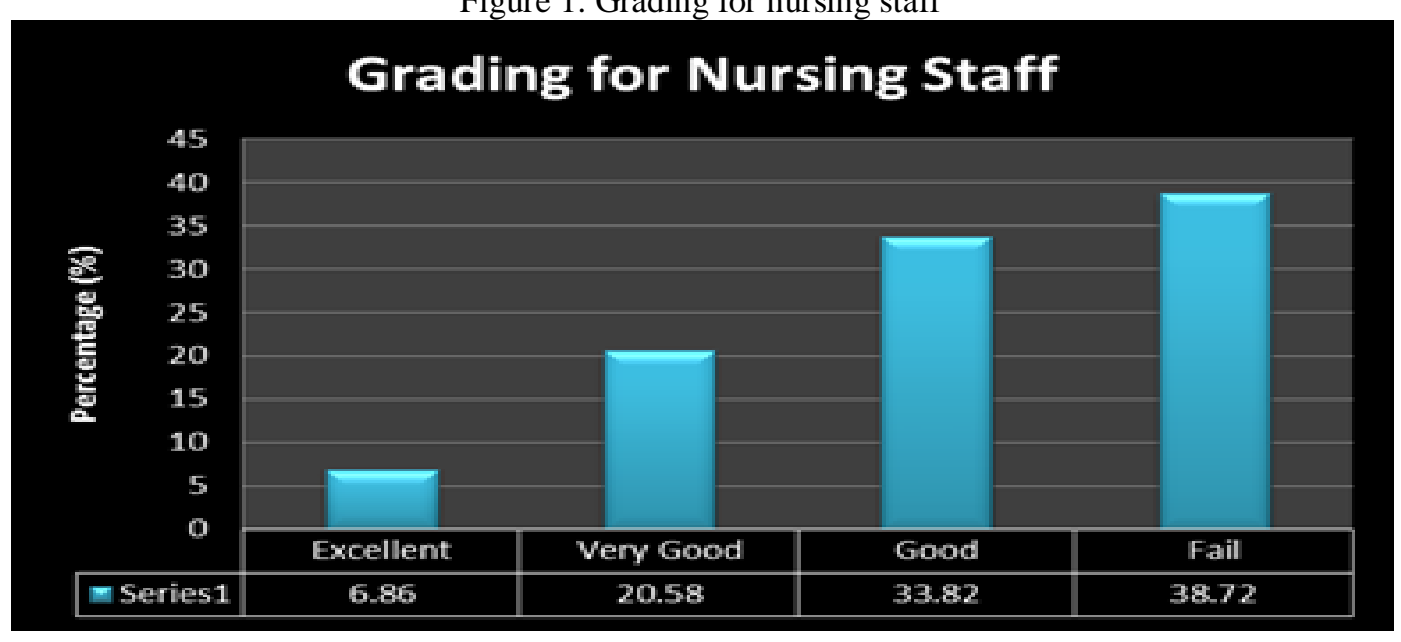


Figure 2: Grading for clinical support staff

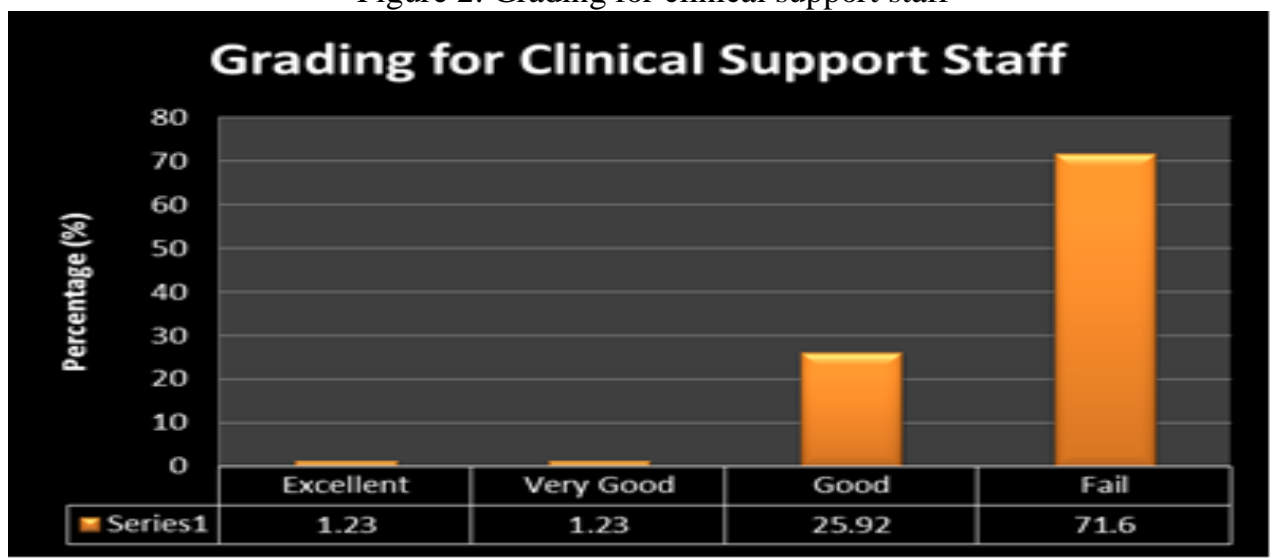

Figure 3: Gradding for non clinical support staff

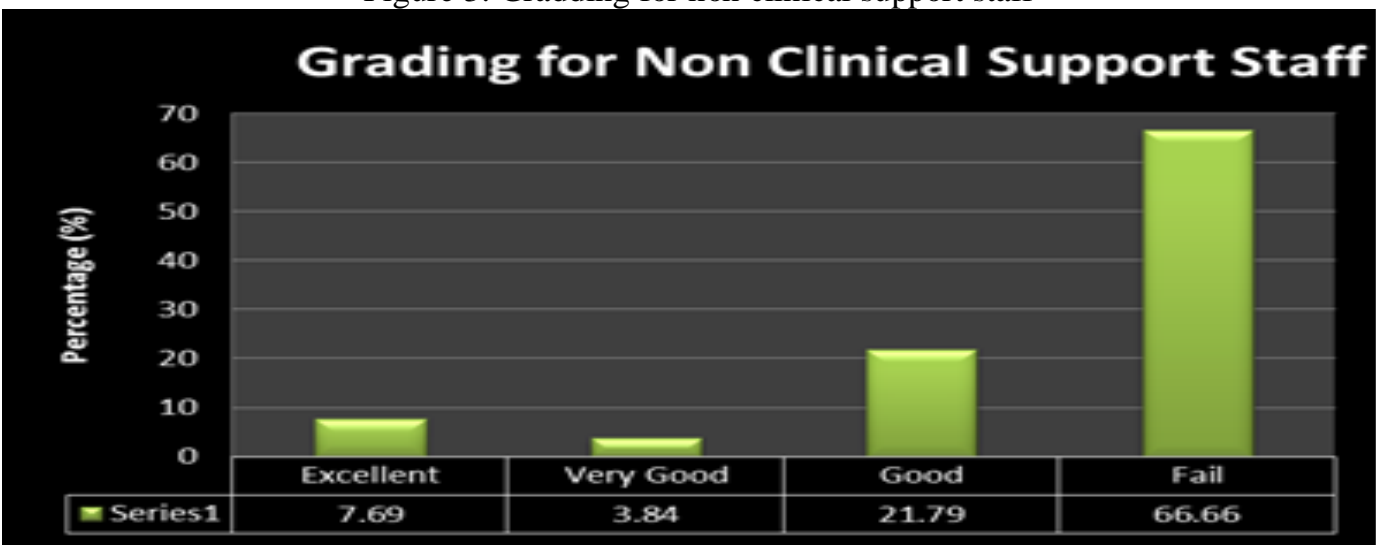

Figure 4: Overall summary for the three categories of staff

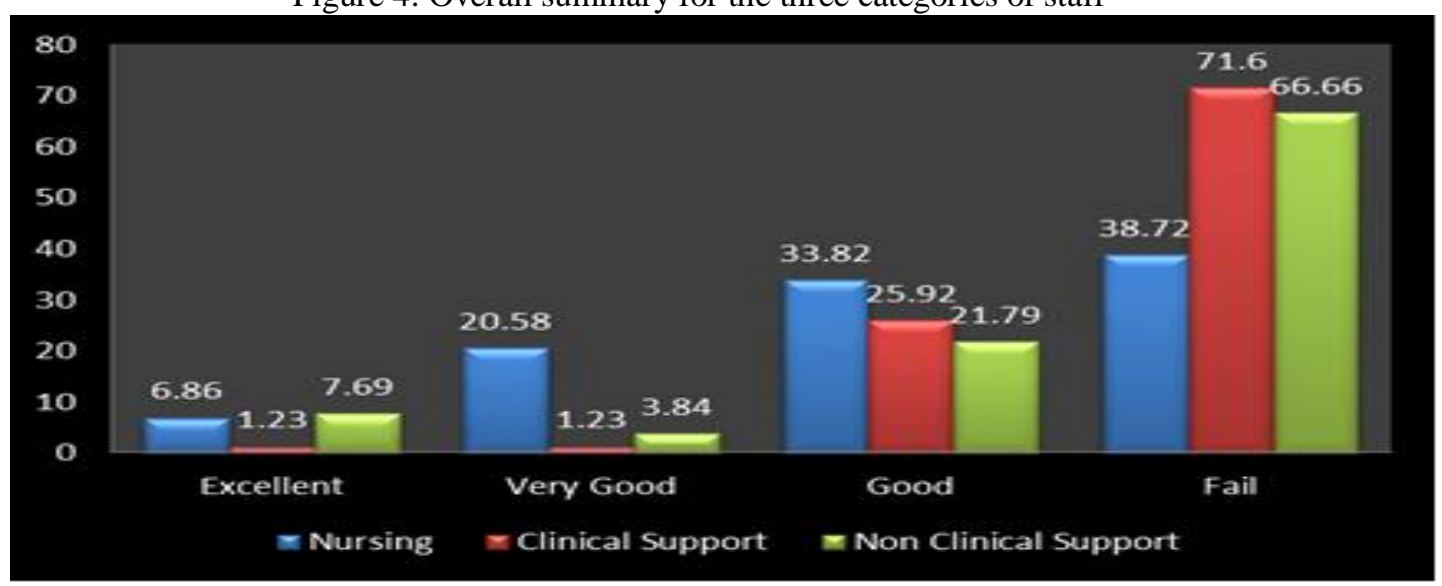

IV. Results Of Waste Audit Conducted In October 2012

Table 4: Total Medical Waste Generated at KPJ Seremban Specialist from 8/10/2012 to 12/10/2012

\begin{tabular}{|c|c|c|c|c|}
\hline Date & Kg & $\begin{array}{c}\text { Total } \\
\text { inpatient }\end{array}$ & Total outpatient & $\begin{array}{c}\text { Kg/patient per } \\
\text { day }\end{array}$ \\
\hline $8 / 10 / 2012$ & 123.65 & 72 & 432 & 0.24 \\
\hline $9 / 10 / 2012$ & 214.9 & 58 & 412 & 0.45 \\
\hline $10 / 10 / 2012$ & 303.4 & 59 & 374 & 0.70 \\
\hline $11 / 10 / 2012$ & 188.5 & 57 & 393 & 0.41 \\
\hline $12 / 10 / 2012$ & 208.9 & 54 & 411 & 0.44 \\
\hline
\end{tabular}


To See The Impact Of Various Interventions On Staff Knowledge And Compliances By Conducting

Average medical waste generated $=208 \mathrm{~kg}$ and $0.45 \mathrm{~kg} /$ patient per day

Table 5: Comparison with other KPJ hospitals

\begin{tabular}{|l|c|c|c|}
\hline & KPJ Seremban & KPJ Penang & KPJ Kajang \\
\hline & & & \\
& & & \\
\hline $\begin{array}{l}\text { Total waste } \\
\text { (kg/day) }\end{array}$ & 208 & $147.5 \mathrm{~kg}$ & $164 \mathrm{~kg}$ \\
\hline $\begin{array}{l}\text { No of patients/day } \\
\text { No of beds }\end{array}$ & 145 & 168 & 318 \\
\hline $\begin{array}{l}\text { Waste generation } \\
\text { rate per patient/day } \\
\text { (inpatient and } \\
\text { outpatient) }\end{array}$ & $0.45 \mathrm{~kg} /$ patient.day & $0.49 \mathrm{~kg} / \mathrm{patient} . \mathrm{day}$ & $0.51 \mathrm{~kg} / \mathrm{patient} . \mathrm{day}$ \\
\hline $\begin{array}{l}\text { Waste generation } \\
\text { rate per bed/day } \\
\text { (bed not occupied } \\
\text { does not count in } \\
\text { the calculation }\end{array}$ & $1.43 \mathrm{~kg} / \mathrm{bed}$ day & $0.87 \mathrm{~kg} / \mathrm{bed}$. day & $1.24 \mathrm{~kg} / \mathrm{bed}$. day \\
\hline
\end{tabular}

Figure 5 : Graphic comparison for KPJ Seremban, Penang and Kajang

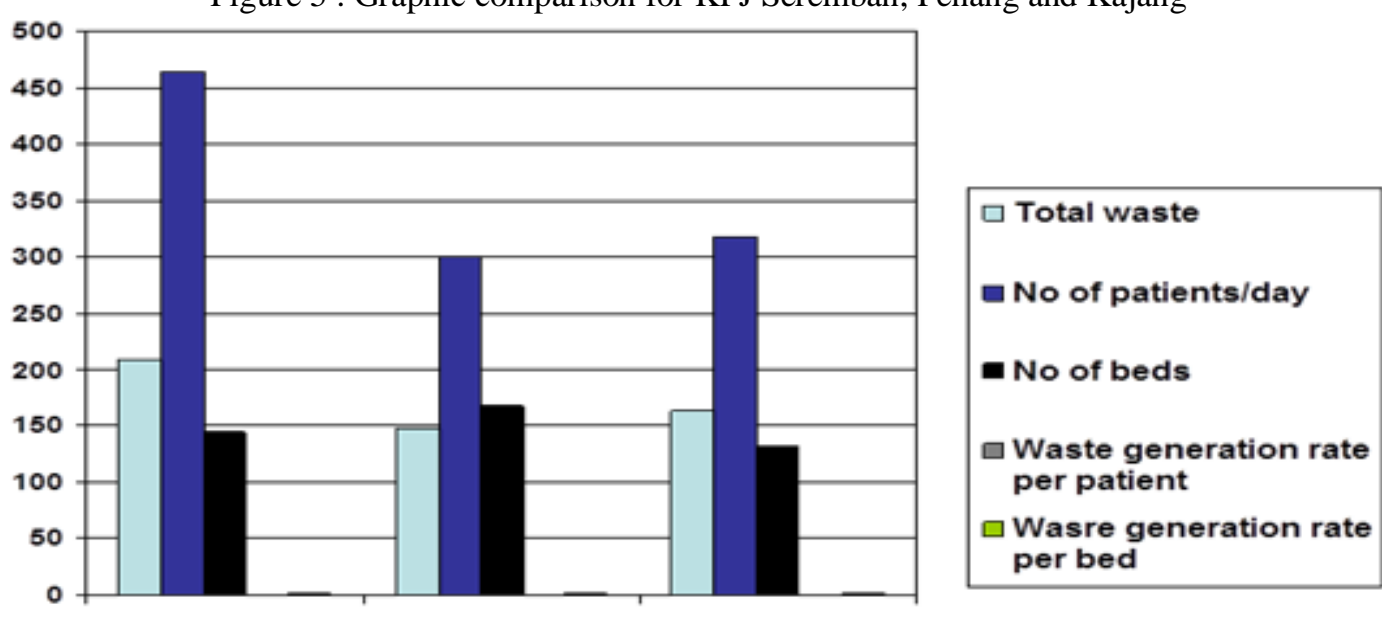

KPJ Seremban KPJ Penang KPJ Kajang

Comparison with overseas hospitals

Table 6: Medical waste generation rate in Dar es Salaam

\begin{tabular}{|l|l|l|l|}
\hline No & Hospital & No. of Beds & kg/patient per day \\
\hline 1 & Hindu Mandal & 70 & 0.37 \\
\hline 2 & Amana, Ilala & 130 & 0.26 \\
\hline 3 & UDSM Health Centre & 24 & 0.41 \\
\hline 4 & Temeke & 140 & 0.15 \\
\hline 5 & Kariuki Mikocheni & 150 & 0.79 \\
\hline 6 & Aga Khan & 88 & 1.30 \\
\hline
\end{tabular}

Average waste generated $=0.55 \mathrm{~kg} /$ patient per day 
To See The Impact Of Various Interventions On Staff Knowledge And Compliances By Conducting

Table 7: Chemical waste generated at KPJ Seremban from 8/10/2012 to 12/10/2012

\begin{tabular}{|l|c|c|c|c|}
\hline \multicolumn{1}{|c|}{ Date } & Kg & $\begin{array}{c}\text { Total } \\
\text { inpatient }\end{array}$ & $\begin{array}{c}\text { Total } \\
\text { outpatient }\end{array}$ & $\begin{array}{c}\text { Kg/patient per } \\
\text { day }\end{array}$ \\
\hline $8 / 10 / 2012$ & 5.66 & 72 & 432 & 0.11 \\
\hline $9 / 10 / 2012$ & 5.66 & 58 & 412 & 0.01 \\
\hline $10 / 10 / 2012$ & 5.66 & 59 & 374 & 0.01 \\
\hline $11 / 10 / 2012$ & 5.66 & 57 & 393 & 0.01 \\
\hline $12 / 10 / 2012$ & 5.66 & 54 & 411 & 0.01 \\
\hline
\end{tabular}

Average chemical waste generated $=\underline{\mathbf{0 . 0 3}} \mathbf{k g} /$ patient $/ \mathbf{d a y}$

In U.S. hospitals hazardous chemical waste generated is less than $0.57 \mathrm{~kg} /$ patient per day http://www.sustainabilityroadmap.org/topics/waste.shtml\#.UdnPO5xCwrw

Table 8: Domestic Waste Generated at KPJ Seremban from 8/10/2012 to 12/10/2012

\begin{tabular}{|l|c|c|c|c|}
\hline Date & Kg & $\begin{array}{r}\text { Total } \\
\text { inpa } \\
\text { tien } \\
\mathbf{t}\end{array}$ & $\begin{array}{r}\text { Total } \\
\text { outpa } \\
\text { tient }\end{array}$ & Kg/patient per day \\
\hline $8 / 10 / 2012$ & 239.50 & 72 & 432 & 0.48 \\
\hline $9 / 10 / 2012$ & 229.00 & 58 & 412 & 0.49 \\
\hline $10 / 10 / 2012$ & 230.25 & 59 & 374 & 0.53 \\
\hline $11 / 10 / 2012$ & 231.15 & 57 & 393 & 0.51 \\
\hline $12 / 10 / 2012$ & 234.75 & 54 & 411 & 0.51 \\
\hline $\begin{array}{c}\text { Average } \\
\text { generation rate }\end{array}$ & 232.93 & & & 0.50 \\
\hline
\end{tabular}

Table 9: Domestic waste generated per $\mathrm{kg} / \mathrm{bed} / \mathrm{day}$

\begin{tabular}{|l|l|l|l|}
\hline Date & $\mathrm{kg}$ & Bed occupied & $\mathrm{Kg} / \mathrm{bed} /$ day \\
\hline $8 / 10 / 2012$ & 239.50 & 72 & 3.32 \\
\hline $9 / 10 / 2012$ & 229.00 & 58 & 3.95 \\
\hline $10 / 10 / 2012$ & 230.25 & 59 & 3.90 \\
\hline $11 / 10 / 2012$ & 231.15 & 57 & 4.06 \\
\hline $12 / 10 / 2012$ & 234.75 & 54 & 4.35 \\
\hline Average & 232.93 & & 3.92 \\
\hline
\end{tabular}

Benchmark $:$ UK $=2.5 \mathrm{~kg} / \mathrm{bed} / \mathrm{day}, \mathrm{USA}=4.5 \mathrm{~kg} / \mathrm{bed} /$ day, France $=2.5 \mathrm{~kg} / \mathrm{bed} / \mathrm{day}, \mathrm{Spain}=3.0 \mathrm{~kg} / \mathrm{bed} / \mathrm{day}$, India $=1.5 \mathrm{~kg} / \mathrm{bed} /$ day

Ref: Hem Chandra, International Society of environmental botanists, Envin News, vol.5.No.3,July 1999,NBRI Lucknow 
To See The Impact Of Various Interventions On Staff Knowledge And Compliances By Conducting

Table 10: Kitchen Waste Generation Rates for KPJ Seremban Specialist Hospital from 8/10/2012 to $12 / 10 / 2012$

\begin{tabular}{|c|c|c|c|c|}
\hline Date & Kg & Total inpatient & Total outpatient & Kg/patient per day \\
\hline $8 / 10 / 2012$ & 100 & 72 & 432 & 0.19 \\
\hline $9 / 10 / 2012$ & 107 & 58 & 412 & 0.23 \\
\hline $10 / 10 / 2012$ & 102 & 59 & 374 & 0.24 \\
\hline $11 / 10 / 2012$ & 106 & 57 & 393 & 0.24 \\
\hline $12 / 10 / 2012$ & 81 & 54 & 411 & 0.11 \\
\hline $\begin{array}{c}\text { Average generation } \\
\text { rate }\end{array}$ & 99.20 & & & 0.20 \\
\hline
\end{tabular}

Table 11: Benchmark with Turkey hospitals

\begin{tabular}{|l|c|c|}
\hline Hospital & No of beds & $\begin{array}{c}\text { Kitchen Waste } \\
\text { (Kg/day) }\end{array}$ \\
\hline Sosyal Sigortalar Kurumu Hospital (Turkey) & 362 & 167 \\
\hline Sivas Numune Hospital (Turkey) & 319 & 118 \\
\hline Sivas Doğumevi Hospital (Maternity hospital) (Turkey) & 150 & 19 \\
\hline $\begin{array}{l}\text { Devlet Demir Yolları Hospital (hospital with 7 } \\
\text { diagnosis and treatment unit) }\end{array}$ & 100 & 13.9 \\
\hline KPJ Seremban & $\mathbf{1 4 5}$ & $\mathbf{9 9 . 2 0}$ \\
\hline
\end{tabular}

Figure 5: Overall waste generation rates of each category in KPJ Seremban Specialist Hospital

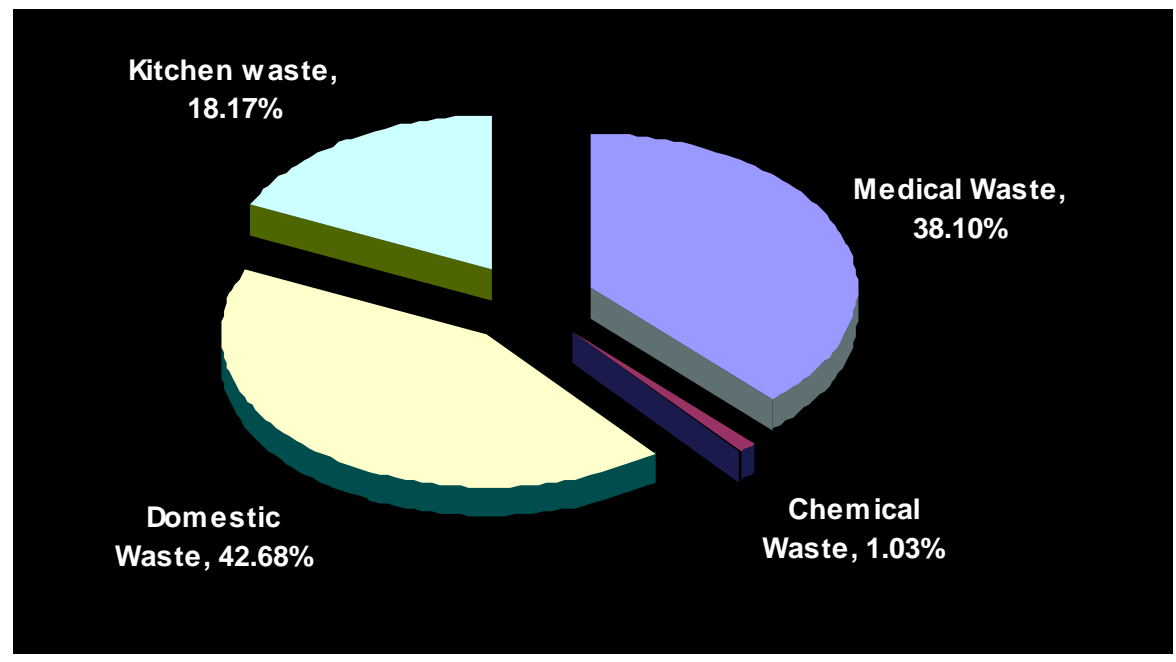


Table 12 :Comparison Analysis Waste Generated

\begin{tabular}{|l|l|l|}
\hline \multicolumn{1}{|c|}{ Hospital } & Hazardous waste & Non Hazardous Waste \\
\hline KPJ Seremban & $\begin{array}{l}39 \% \text { (Clinical \& } \\
\text { Chemical waste) }\end{array}$ & $\begin{array}{l}\text { 61\% (domestic \& } \\
\text { Kitchen waste) }\end{array}$ \\
\hline Malaysia Hospital & $\begin{array}{l}20 \%-40 \% \text { (Clinical \& } \\
\text { Chemical Waste) }\end{array}$ & $\begin{array}{l}60 \%-80 \% \text { (Domestic \& } \\
\text { Kitchen waste) }\end{array}$ \\
\hline $\begin{array}{l}\text { American Hospital } \\
\text { Association }\end{array}$ & $\begin{array}{l}15 \% \text { (Clinical \& } \\
\text { Chemical waste }\end{array}$ & $\begin{array}{l}85 \% \text { (domestic \& } \\
\text { Kitchen waste) }\end{array}$ \\
\hline
\end{tabular}

For the survey conducted in April 2012, 500 questionnaires had been distributed to various categories of staff. However only 363 questionnaires were returned to the management which is $72.6 \%$ of the sample. For the first question on how many types of schedule waste , only $13.50 \%$ can give the right answer. For the second question on how best to describe the schedule waste, only $74.66 \%$ had given the right answer. $26.17 \%$ had given the right answer for the question related to the collection time for clinical and general waste. For the fourth question on who should collect the waste, $92.20 \%$ had given the right answer . $65.84 \%$ had given the right answer on color coding of waste bin and $79.34 \%$ on color coding for waste bag. For the last question on PPE, $85.67 \%$ had given the right answer. In conclusion the understanding of staff on hospital waste management was poor and this will effect their compliances. The grading given was based on the guidelines produced by University of Economy, Parague which had given excellent rating between 90-100 points, 75-89 points as very good, 60-74 as points as good and $<59$ points as fail. Based on this rating, for nursing staff, $6.86 \%$ were rated as excellent, $20.58 \%$ as very good, $33.82 \%$ as good and $38.72 \%$ failed. However for nursing the understanding should be excellent because they are the main players in term of waste management. For clinical support staff, $1.23 \%$ were rated as excellent, $1.23 \%$ as very good, $25.92 \%$ as good and $71.6 \%$ failed. The failure rate were higher compared to nursing staff. For non clinical support staff the excellent rate were $7.69 \%$, very good $3.84 \%$, good $21.79 \%$ and failed $66.66 \%$. The grading for non clinical were much better than clinical support staff.

Since the grading were not satisfactory for all categories of staff, the management had implemented the following interventions:

-producing book as a guidelines in managing hospital waste

-continuous teaching for all staff of various categories in managing hospital waste

-monthly briefing at every department

-monthly round by a team headed by outsource officer who is in charge of waste management to check the compliance

-producing guidelines on audit of waste

-training of head of departments on how to conduct waste audit

Those programs were carried out for five months from May to September 2012.In order to see the impact of those interventions in improving staff knowledge and compliances to the guidelines, waste audit was carried out in October 2012 to see the outcomes of various categories of waste generated based on the audit check lists .The outcomes were later compared with the national and international benchmarks. Based on the waste audit conducted from $8 / 10 / 12$ to $12 / 10 / 12$, the average medical waste generated were $208 \mathrm{~kg}$ and $0.45 \mathrm{~kg} /$ patient/bed. As a benchmark, average medical waste generated by KPJ Penang were $147.5 \mathrm{~kg}$ and $0.49 \mathrm{~kg} / \mathrm{patient} / \mathrm{bed}$ where as for KPJ Kajang, the average medical waste generated were $164 \mathrm{~kg}$ and $0.51 \mathrm{~kg} /$ patient $/$ bed. Therefore the total amount of waste generated by KPJ Seremban were higher than KPJ Penang and KPJ Kajang. However in term of $\mathrm{kg} /$ patient/bed the amount generated by KPJ Seremban were slightly lower. When compared to international hospitals such as Dar es Salaam(Tanzanian district hospitals), the average waste generated were $0.55 \mathrm{~kg} /$ patient/ day. Therefore KPJ Seremban was more efficient in managing medical waste. In term of chemical waste generated, based on the audit conducted from 8/10/12 to $12 / 10 / 12$, the average chemical waste generated were $0.03 \mathrm{~kg} /$ patient/day. When compared to U.S hospitals ,their rate were $0.57 \mathrm{~kg} / \mathrm{patient} /$ day which is much higher than KPJ Seremban.

Based on the audit conducted from $8 / 10 / 12$ to $12 / 10 / 12$, domestic waste generated in KPJ Seremban were $3.92 \mathrm{~kg} / \mathrm{bed} / \mathrm{day}$. For international standards, domestic waste generated in UK=2.5kg/bed $/ \mathrm{day}$, USA $=4.5 \mathrm{~kg} / \mathrm{bed} / \mathrm{day}$, France $=2.5 \mathrm{~kg} / \mathrm{bed} / \mathrm{day}$, Spain $=3.0 \mathrm{~kg} / \mathrm{bed} / \mathrm{day}$ and India $=1.5 \mathrm{~kg} / \mathrm{bed} / \mathrm{day}$. Therefore KPJ Seremban is between Spain and USA.

For kitchen waste, the average amount generated between 8/10/12 to 12/10/12 were $99.20 \mathrm{~kg}$. For international benchmarking, the average amount of kitchen waste generated in Turkey were $79.2 \mathrm{~kg}$ which is slightly lower than KPJ Seremban. 
Through the waste audit in KPJ Seremban, it was found that medical waste generated were $38.10 \%$, chemical waste $1.03 \%$, domestic waste $42.68 \%$ and kitchen waste $18.17 \%$

When compared to both national and international benchmarking, the clinical and chemical waste generated in KPJ Seremban were 39\% compared to 20\%-40\% for Malaysian hospitals and 15\% for American hospital. For domestic and kitchen waste, KPJ Seremban generated 61\% compared to 60\%-80\% for Malaysia hospitals and $85 \%$ for American hospitals. Therefore KPJ Seremban was within the national and international standards.

\section{Conclusion}

The waste management program conducted in KPJ Seremban had improved staff compliances in reporting, handling, segregation and disposal of hospital hazardous and non hazardous waste. The organization had identified average rate of waste generated and able to benchmark with other national and international hospitals' guidelines. This will help the hospital to ensure that wastes are managed properly to reduce the impact on the environment.

\section{References}

[1]. Environmental Quality Act, Government of Malaysia,1974,1-2

[2]. Federal Subsidiary Legislation, Environmental Quality (scheduled waste) Regulation, Government of Malaysia, 1989,1-7

[3]. Safe management of health care waste, RCN Guidance,2007,3-14 http://www.who.int/topics/medical_waste/en/

[4]. http://web.weatherfordisd.com/EmployeesLinks/tools/GradeCalc.asp)

[5]. http://www.sustainabilityroadmap.org/topics/waste.shtml\#.UdnPO5xCwrw

[6]. Hem Chandra, International Society of environmental botanists, Envin News, NBRI Lucknow, 1,5,3,1999, 1-10

[7]. African Journal of Environmental Science and Technology 5,10,2011, 815-833

[8]. S.Altin et. Al, Determination of hospital waste composition and disposal methods: a case study, Polish Journal of Environmental studies $12,2,2003,251-255$

[9]. African Journal of Environmental Science and Technology, 5,10, 2011, 815-833

[10]. S.S.Razali, Clinical waste handling and obstacles in Malaysia, Journal of Urban and environmental Engineering,2010,1-4 